\title{
AN EXPERIMENTAL STUDY ON AUDITORY RESPONSE IN HUMAN EGG BY ARC
}

By

\author{
MINORU TORIYAMA, TsUTOMU MATSUZAKI, H HoNORI HAYASHI \\ and Sotaro FUNASAKA
}

From the Department of Oto-Rhino-Laryngology Faculty of Medicine, University of Tokyo (Director: Prof. I. Kirikae)

Relationship between evoked potential and stimulus intensity under various consciousness was studied by an analog-type ARC.

In a certain depth of sleep, evoked potential increased as a function of stimulus intensity up to $40 \sim 50 \mathrm{~dB}$, but it was remarkably influenced by subject's consciousness. Average response to tone pips was most clearly observed in the drowsy and hump stage.

The facts suggest that for the evaluation of auditory threshold by EEG response it is important to monitor the subject's consciousness during examination.

Finally the results were discussed from a neurophysiological point of view.

\section{電子加算機による脳波聴性反応に関する塞験的研究}

$$
\begin{aligned}
& \text { 東京大学医学部耳厸咽啒科教室（主任：切替一郎教授） }
\end{aligned}
$$

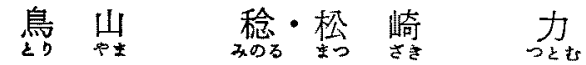

$$
\begin{aligned}
& \text { 林 宏 典・船 坂 宗太郎 }
\end{aligned}
$$

\section{第 1 章緒言}

1939 年 Davis et al 1) 住睡眠時の人間頭皮上から音 摔刺激による誘発反応を観察し，これを K-complex と 呼称した. 爾後, この誘発反庁を指標として幼小胃の聴 力を他覚的に検査する試みが多くなされている。

奻小胃の他覚的聴検の場合, 被検者の動きを避けるた め睡眠時に桧查が施行されるが，多くの研究者によつて 脳波上の聴性反応の出現が被検者の睡眠の深さに著しく 左右されることが報告されている，しかる，聴性反応の 检出される至適条件はきわめて怗い睡肵深度であり，動 摇し易い，そのため適切な睡眠状態を維持することが難 しい.

この問題を解決するために，反応の判定に脳波の記録 を視診する方法から，それを統計的に処理する方法 2)， いくつかの記録を重权合わせて反応を楒め易くする法 8)，代数的に加算する法 ${ }^{4}$ と方法諭的に改善が加文られ てきた，近年，誘発電位を電気的に加算し，反応を平均
波形として検出する目的でこの分野に電子加算機が導入 された ${ }^{56)}$. この装置の原理は多回数の音響刺激に相関 した誘発電位を加算，平均化するるので，これにより刺 激と無関係に生ずる自発電位は平均化により需となり， 反応波形のみが発達，浮彫りにされる。

今回，我々はアナログ型電子加算機を用いて，脳波聴 性反応に及活寸因子を被検者の睡眠深度之音留制激の強 さに限定し，その出現率に対する関係を検索したのて報 告する、諸賢の御批判を仰ぐ次第である。

\section{第 2 寞虽方法}

被檢者は德力正常成人男女 12 名である。被㭘者はす ベて防音シールド室に安静仰卧し，覚醖より自然睡眠ま での種々の状態を任意にとつた。

音響刺激はオージオメーターを用い，0.5KC 及び 1 $\mathrm{KC}$ の純音を可聴閔值上 $\mathrm{OdB}$ から $5 \mathrm{~dB}$ 段階で $55 \mathrm{~dB}$ までスピーカーを通し与えた．刺激音は電子管スイッチ にて切断し，持続 100 ミリ秒，立ち上り下り 10 ミリ移 
とした。刺激間隔は原則として2 秒とした。

音響刺激下の脳波は被検者の右前頭部及び右頭頂部よ り単極あるいは双極誘導した。脳波は直接脳波計に接続 する他, 一部電子加算機に誘導し，その变動を加算せし めた，加算結果洅び脳波計に導き，脳波記録用紙上に 描記させると共に，陰極線 オッシロスコープにも誘導 し, 同時観察, 記録した.

電子加算機は記憶回路として永久磁筑テープを利用し たものである.自らの駆動装置より刺激ショックを発す ると共に，その時点より次の刺激時点までの脳波を磁気 テープ上に記録し，さらに次の刺激に同期してそれを再 生し，次の脳波を加算して行く．この繰作が連綕周期的 に反復されると，各刺激による脳波変動が刺激時点を一 较させて加算される。このため音響刺激とその潜時，位 相などにおいて相関を持つ誘発電位のみが一定の方向に 発達し, 一方, 不規則な自発脳波は加算過程の内に相殺 されて零となる. その結果, 誘発反応が明確に浮崕りに される原理である。

実験装置を図 1 亿示す

图 1 Block Diagram

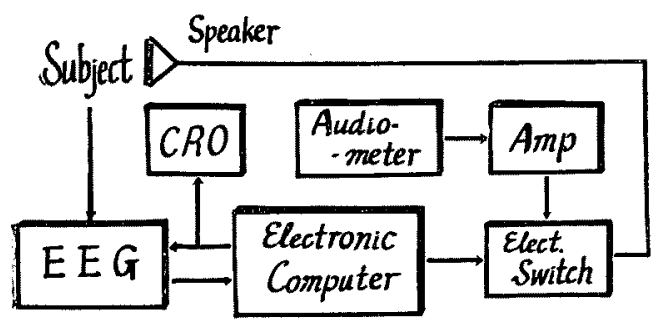

第 3 章 実験 結 果

(1) 脳波㯖性反応の特徵

音響刺激より脳波上に現和れる变化には従来, 所謂 K-complex, spindle 誘発, $\boldsymbol{\alpha}$ 波遮断，電位抑制などが 報告されているが，こ〉では多回数の加算結果, 平均波 形として認められた反応の性状について記述する。

\section{(a) 反応波形}

音響誘発反応の典型的波形は第一陽，陰性波 $\left(\mathrm{P}_{1}, \mathrm{~N}_{1}\right)$ とそれに続く中持続の長い第二陽・陰性波 $\left(\mathrm{P}_{2}, \mathrm{~N}_{2}\right)$ の四相性であつた（図2のa）。しかし，反応䉓位は一 般に $\mathrm{N}_{1}, \mathrm{P}_{2}$ が最も大きく，次いで $\mathrm{N}_{2} て ゙ ， \mathrm{P}_{1}$ は小さ くしばしば認められないことがあつた，このため $\mathrm{N}_{1} \mathrm{P}_{2}$ $\mathrm{N}_{2}$ の三相性あるいは $\mathrm{N}_{1} \mathrm{P}_{2}$ の二相性の波形孔見出され む(図2のb及びc).
図 2 誘発反応の加算波形

(a)

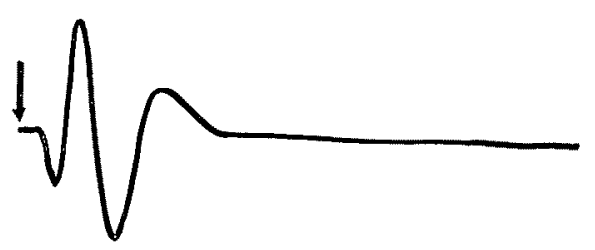

(b)
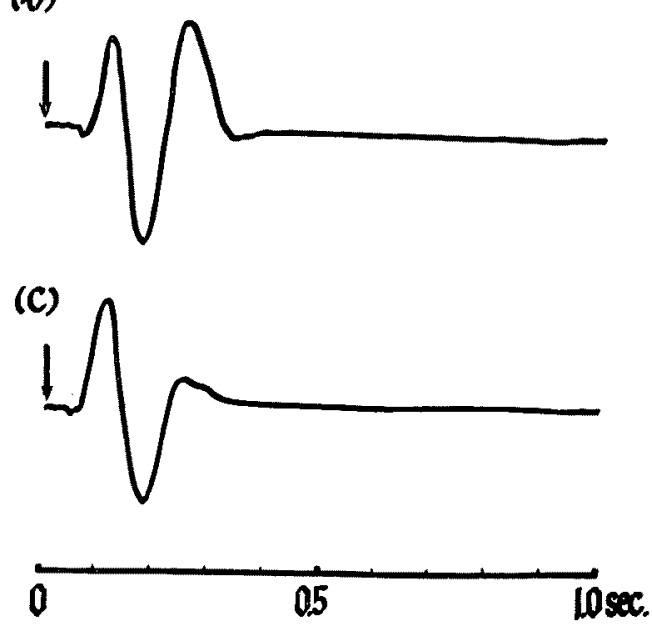

表 1 平均波形の反応潜時

(単位ミリ秒)

\begin{tabular}{c|c|c|c|c|c}
\hline cps & $\mathrm{dB}$ & $\mathrm{P}_{1}$ & $\mathrm{~N}_{1}$ & $\mathrm{P}_{2}$ & $\mathrm{~N}_{2}$ \\
\hline \hline \multirow{3}{*}{1000} & 35 & 61 & 96 & 156 & 206 \\
& 40 & 70 & 106 & 147 & 204 \\
& 45 & 70 & 108 & 160 & 213 \\
& 50 & 60 & 101 & 146 & 189 \\
\hline \multirow{3}{*}{500} & 40 & 77 & 125 & 173 & 244 \\
& 50 & 68 & 103 & 150 & 205
\end{tabular}

（b） 反応の潜時及び持続

平均波形の各ピーク潜時は $\mathrm{P}_{1}$ が 50〜70ミリ秒， $\mathrm{N}_{1}$ が70〜120ミり秒, $\mathrm{P}_{2}$ が 140〜170 ミリ秒, $\mathrm{N}_{2}$ が 180 〜250ミリ秒と計測された。 また反応の全持続は約 300 ミリ秒であつた（図2)，表に一一被検者の反応の潜时を 示寸 反応潜時の個体差はほとんど認められなからう。

(c) 加算回数之誘発雷位

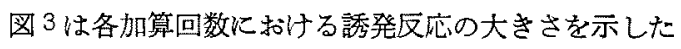
むのである．各刺激音の強さで至ざ線的に誘発電位は 增加している．この加算過程中, 視診上個々の誘発反応 
図 3 加算回数と反応部位

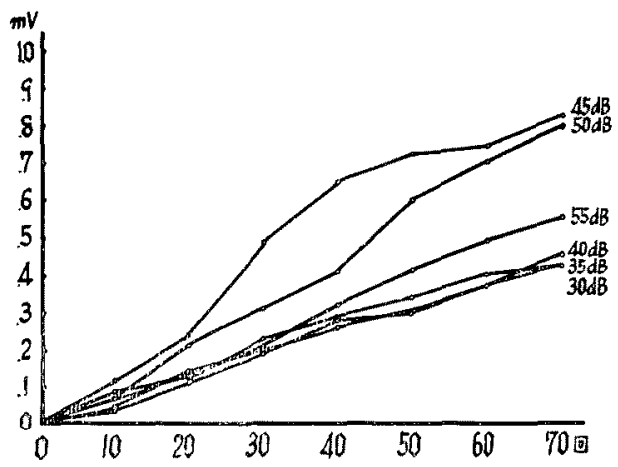

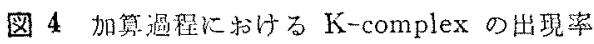

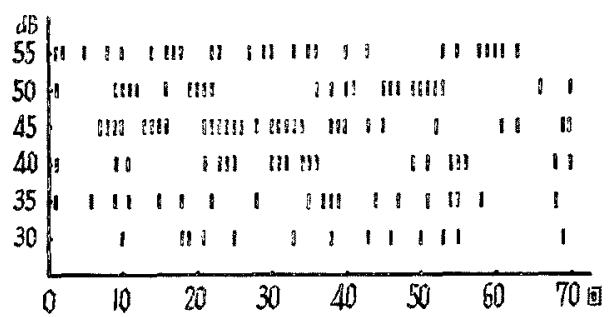

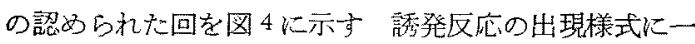
定の傾问は認奶られないが。招上そ均等に現われてい る. $45 \sim 50 \mathrm{~dB}$ に最も多く連続的に出現している.

\section{(II) 誘発電位と音湖刺激の強さ上の関係}

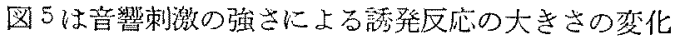

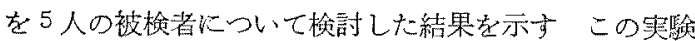

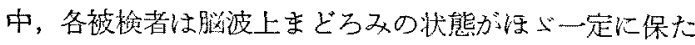
れていた，結果は 45〜50dB の強さで粉発電位は最大

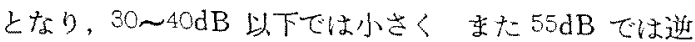

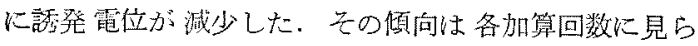

図 5 刺激の强さと誘発部位

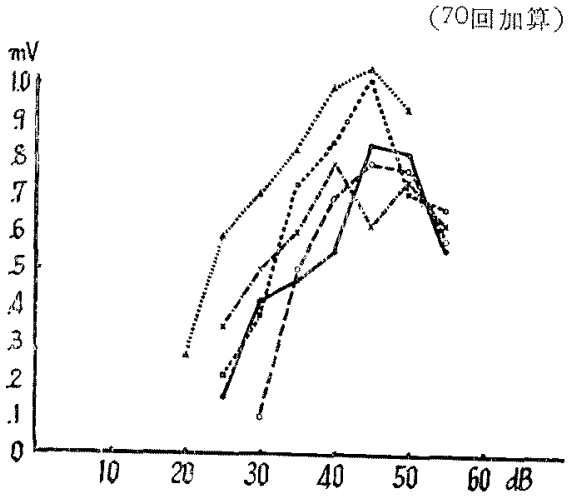

図 6 刺激の強さと反応潜時

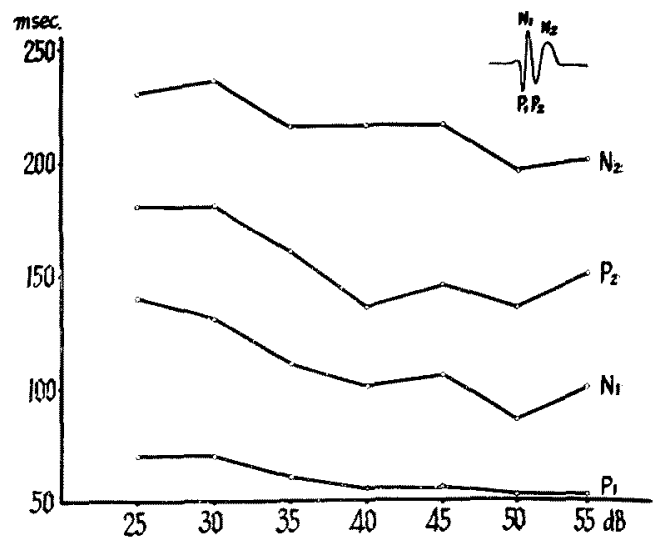

れ，回数と其に藩明となつた。こ机は他被検者，各周㳊 数に沶いて子共通して見出された特徽であつた。

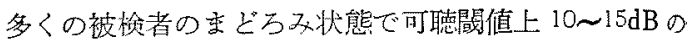
強さで反応波形が認められた。

刺激音の㧧さと反応波形との間に恃特買な関係が見ら れなかつたが，20〜30dB 以下の弱い刺激では初期陽住

图 7 各意識状態に括ける平均波形

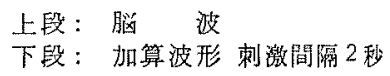

Awake

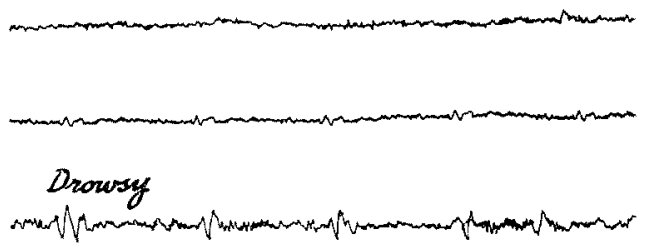

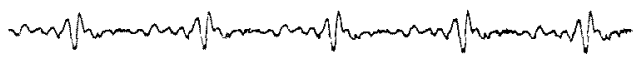

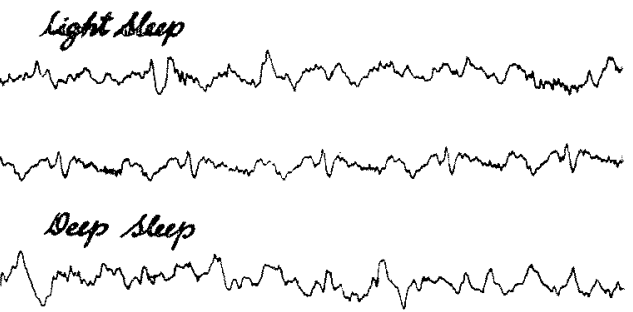




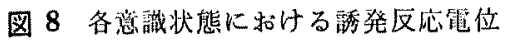

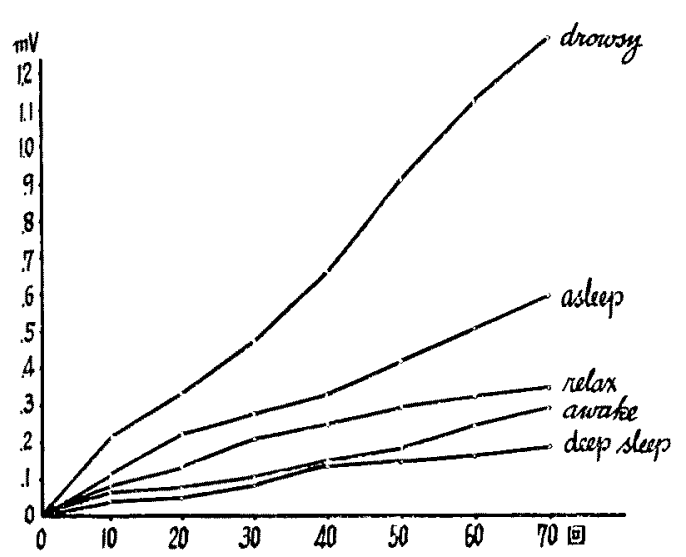

波 $\left(\mathrm{P}_{1}\right)$ が不明瞭のことが多からた、刺激穴の強さに上 る双広潜時の变化の一例を図6に示す 刺激音の強さと 共に潜時の短縮する傾向が見られた。

〔四〕誘発電位と意識状態との関係

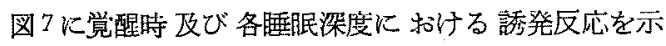

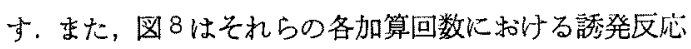
の壮方を示したものである。誘発反応はまどるみ及至浅 、睡眠状態和いて最も出現しやすく，その電位も加算 回数と共に著明に增大した，各意識状態での反応波形は まどろみの状態で典型的な四相性を呈したのに対し，覚 醒あるいは深睡眠時には $\mathrm{P}_{1}, \mathrm{~N}_{2}$ の明確でないものが見 られた。，また意識状態に上る反応潜時の変動は覚醒時か ら深睡眠時に行くにつれて，特に $\mathrm{P}_{2}, \mathrm{~N}_{2}$ の掘い成分の 潜時が延長することが観察された。

以上の結果より誘発電位に対する音の強さと意識状態 の両者が影響することが明らかにされた，意識状態の数 量的表現が不可能のため音の強さと効果の上で量的に比 較できないが，多くの実験経験より誘発電位の增加には 被検者の意識状態が最大の因子として㗢くことが推測さ れた。

\section{第 4 章 総括並びに考按}

幼小児の㴔力検查では被検者の無関心，注意力久如， 知能未発達などの理由から他覚的判定に頼らねばならな い，その他覚的指標としては古来，条件索反射を利用す るもの，瞬目反射，篤愕反射を利用するもの，さらに生

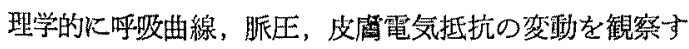
るものなどが㹲接されているが，その一つに脸波聴性反 応を指標としたカ法がある。

人間の睡眠中に省響刺激を与えると，その脳波にある
特定の反応の生ずることが知られていたが，Doerfler? (1948) はこの誘発反応を他覚的聴検に応朋することを 示唆した。これに続いて, Tato8) (1949), Marcus et al 9)10) (1949, 1951), Gidoll11) (1952), Perl et al 12) (1953), Derbyshire et al ${ }^{13) 14) 15)}(1955,1956,1958)$, Suzuki et al ${ }^{3)}$ (1957), Withrow et al ${ }^{16)}$ (1958), Ortiz-Estrada et al17) (1963) らがそれに関する業績を 報告, 本邦化括いて子伊藤18) (1939)，山本 ${ }^{19)}$ (1954), 浅輸 20) (1959)，板倉 21122）(1957，1959），河村 28)24) $(1959,1963)$, 長畑 ${ }^{26)}$ (1961), 坂本 (1963)26) 5Kよ つて脳波に上る他覚的聴榆の知見が発表されている.

それら多くの論文発表にか力わらず，幼小児の脳波他 覚的聴検には二つの大きな問題があつた，その一つは他 覚的検查による聴力闖值と標準㯖検による闒值之の相違 の検定であり，もら一つは被検者の意識状態により聴性 反応の出現率が著しく左右されることの解決法であつ た. 我々は今回誘発反応を電気的に加算し, 平均波形と して観察するといら新しい手法により，従来の聴检と些 か異なつた観点からこの二つの主題を検討した。. 次に上 記の結果を今迄の業䋶と比較, 考察を加えて見ないと思 5 .

\section{[1] 誘発反応の特徽}

Davis et all) (1939) は睡眠時人間脳波の聴性反応を $6 \sim 8 \mathrm{c} / \mathrm{s}$ の一連の比較的規則正しい波がデルタ徐波の 上に重罟すると記載した，艺の後 Marcus et al 9)10) (1949, 1951), Gidoll11) (1952) は音響刺激によつて脑 波が睡眠から覚醒バターンに移行する現象を指標とした が，Perl et al ${ }^{12)}$ (1953) は脳波聴性反応を（i） $\alpha$ 波抑 制, (ii) 党醖脳波への移行, (iii) 多相性電位, (iv) K-complex の四つの型に分類した. 以後, この四つの反 応型は多くの学者により聴性反応の判定基準として採用 されている。

今回の我々の加算結果では誘発反応の本態は陽陰陽陰 の四相から成る波形であることが明らかにされた，しか し, 最初の陽性波と最後の㓌性波とは電位の小さいこと が多く，時に検出し得ないときには波形は三相性あるい は二相性として観察された. 所謂 K-complex の波形に ついては従来視㟝上より判定されたものであつたが， Davis ${ }^{27)}$ (1939), Abe ${ }^{28)}$ (1954) らは党䤏時の頭皮上か ら陰陽陰性の三相波形を観察している。亦た，Gastaut 29) (1953), Bancaud et al ${ }^{50)}$ (1953) らは頭頂部机括忷 る陰性波がこの反応の主要素を成すとして vertex spikes とこれを呼んだが， Roth et al ${ }^{31)}$ (1956)によれば 
それらの初期㓌性波に先行する小さい陽性波が認められ るといら.ささらに Derbyshire et al14) (1956) の如く $6 \sim 15 \mathrm{c} / \mathrm{s}$ の速波が $2 \sim 5 \mathrm{c} / \mathrm{s}$ の徐波の上に重畳したもの といら記述がある。事丰，K-complex には多くの var iationがあり，個ヶの反応の観察では一定の波形を定義 するのは至難のことであるう。我々の加算波形から推測 するに，多くの学者が指摘している K-complex の速波 成分汢一定の潜時，位相を有するものでなく，徐波成分 のみが K-complex の本質をなすものと思われる．

次に，この聴性反応の潜時に関しては覚醒時 Davis 27$)$ (1939) の約30〜40 ミ秒, $\mathrm{Abe}^{28)}$ (1954) の90〜110 ミリ秒，また，板倉 ${ }^{21)}$ (1957) の0.2 秒以内, 北尻 ${ }^{32)}$ (1958) の0.1〜0.2 秒とい弓記载があり，一方，睡䣕時 には Davis et al1) (1939) は約 100 ミリ秒, Perl et a112) (1953) は150 200ミリ秒とし, さらK Gastaut 33) (1954) の65士20ミ纱, 板倉 ${ }^{21)}$ (1957) の0.2秒

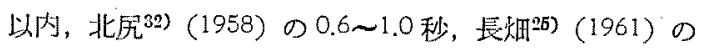
70 ９ミリ秒という報告がある。我々の観察した平均波 形では第一の陵隍波の潜時が 50〜120 ミリ秒，第二の陋

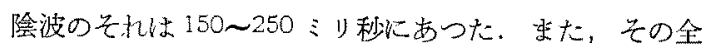
反応過程は約 300 ミリ秒と算定された，これらの事笑上 りこの禖発反応は非常に多数の神経細胞を杂して皮質に 投射されたものであることが推测される。

さて，これらの誘発反応が中枢神経系の生理機構の如

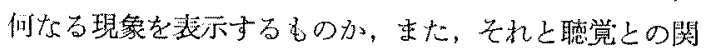
連性について考察することはそれ自体興味深い、状かりで なく，聴柣という本来の応用目的からも重要なことであ る. 反伈と聴力との閉連度については後章で諭ずること とし，こ〉では反応の発生機序に関して少しく考察主 る、既にこれに関しては鳥山年（1954）の詳細な論考が あるが，著者らは第一陽除性波 $\left(\mathrm{P}_{\mathrm{I}}, \mathrm{N}_{\mathrm{I}}\right)$ は大脳皮質連 合領の活動電位を反映し，上り遅い符二陽陰性波 $\left(\mathrm{P}_{2}\right.$, $\mathrm{N}_{2}$ ) は本来動物に備わつた本能的鳘悌反射の電位を表

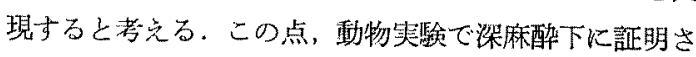
れている二次反応 ${ }^{35) 36)}$ とこの遅い成分との類推が多く の矿究者により諭ぜられている129930311)。しかし一力に おいては $\mathrm{P}_{1} \mathrm{~N}_{1}$ が棘状を成し， $\mathrm{P}_{\mathrm{g}} \mathrm{N}_{2}$ が緩やかな波状を

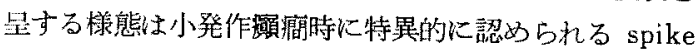
and wave の波形々の関連屯推定され， $\mathrm{P}_{1} \mathrm{~N}_{1}$ が $\mathrm{P}_{2} \mathrm{~N}_{2}$ と起源的に別倜のるのであるか，あるい灶一連の神経活 動を示すむのか推測の域を出ない，今後の㭘討を要する 点であるら。

\section{〔II 音響刺激の強さと誘発䉓位}

脳波聴性反応を指標とした他覚的聴検により，とれ性

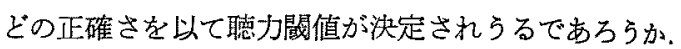
この問題に関して従来の業績を通臨するに，先ず Perl et al ${ }^{12)}$ (1953) は自覚可恥閶值上 $40 \mathrm{~dB}$ あるいはそれ 以上で $\boldsymbol{a}$ 波の抑制が起ると述べ, Suzuki et al ${ }^{3)}$ (1957) は全観察例の $82.6 \%$ で 20dB の差を起觉なかつたと報

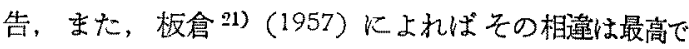
$20 \mathrm{~dB}$ であつたが，大多数は $\pm 5 \mathrm{~dB}$ 以内の值であろう といち. Derbyshire ${ }^{14) 15)}(1956,1958)$ は德性反応が少 くとも50\%認められる場合を他覚的可缌閥值之定めて自 覚成值と比較し，平均士18dB の相違が認められたと 述べ，浅輪20)(1959）は党醌時であるが重ね合わせ法で $20 \mathrm{~dB}$ あるい忙去れ以下であつたと記載，河村 23)24) (1959，1963）も15〜20dB 以下が大部分 と発表してい る.ささらに長畑 ${ }^{25)}$ (1961) は6才以上の年長児 7例で両 検査法の閾值測定結果を比較し，その差 $\pm 25 \mathrm{~dB}$, 平均 $8.7 \mathrm{~dB}$ と比較的よく一致したと報告している，以上の成 績は被検者の条件によつて多少数值が異なるにしても， 要約すれば他覚的聴検によつて 自筧聴力閵值と凡そ20 $\mathrm{dB}$ 以内の精度で閾值が決定されることを物語るもので 步る。

我々の加賞法に上る結果では同様被検者の意識状態に 上り反応出現性が大きく左右されたが，最も現われ難い 覚醒時でも15〜20dB の強さで反応が認められ，まど ろみ状態では $10 \mathrm{~dB}$ で反応を判定し得た例もあつた。 しかるに $5 \mathrm{~dB}$ の強さでは加算回数を如何に增加させて も反応は観察できなかつた。

この現象は何を意味するか，著者らはそれを誘発反応 の発生機構に由来するもの之考克，これは技術的方面の 改良によつても短縮できない限界之推測する。即ち，既 K Gastaut ${ }^{29)}$ (1953) らはこの反応の本態鳘悌反射を 想定しているが，その反応系に打いて聴力閵值のさらに 上に反射を惹起せしめるもら一つの關值があり，その闒 值上の入力がないとたとえ音が聴えていても誘発電位は 生しないと考えれば説明できる、両䦭値の差がこの自・ 他党:聴力閾值の相違と考えることができよう。これを言

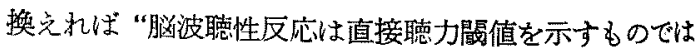
ないが，反応の発現に聴覚の存在も不可欠な要素である ことから推して，ある一定の差を予測して聴力間値を判 定する限り有意㬢なるのと思われる”

次に，誘発反応の闒值上で音響刺溦を增加させて行く と反応電位も活が直線的に漸增したが，40〜50dBで最 
大值を示し，55dB では電位は逆に減少の傾向を見せ た。この現象は誘発電位が中种神絽系の出力を表琴与る bのとすれば，感覚入力に対して出力が一定限度で飽和 状態になることを示し興味樑い、これらよりさらに中枢 に和いて感覚入力量が調節されている機構が想像され 万。

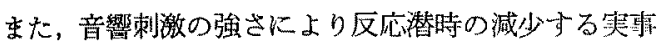
は Derbyshiye et al ${ }^{15}$ ) (1958) も指摘しているが, こ れは従来の電気生理学的業績 ${ }^{37}$ (38) からも認められてお

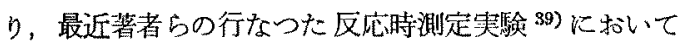

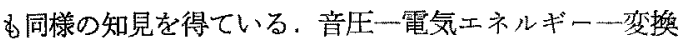
過程に角連した共通の現象と思われる。

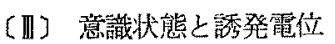

誘発反応の出現深が被検者の意識状熊により大いに左 右されることは多くの学殾にり，既に発表されている とこるである。

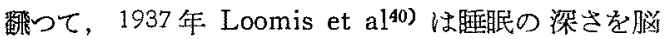
波所見上，A．B．C. D. E の 5 段階に分頪したが，さ SK Davis et a141) (1937) は入眠期の A. B. 段階に 関して心理生理学的観点から検請を加穴た。この業續は 脳波学研究初期にあって優れたものであり，現在に水い

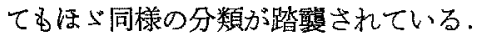

さて, Davis et all) (1939) は自らの分類による睡眠 各期での誘発反応を検索した結果，K-complex は睡眠 $の C$ 期即ら spindles stage に最る出現し易いと結諭し た. 次いで Perl et al 12) (1953) \& K-complex は浅 い睡眠 early spindle stage によく現狆ると述べ，

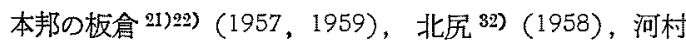
23)24）(1959，1963)，長畑 25) (1961） 5多同様の知見を 得ている。また， Roth et al\$1) (1956) は麻酔による睡 眠下では脳波上低電位速波活動の上き $\mathrm{K}$-complex が最 も安定して認められたと報告している。

上記の業績からして脳波聴性反応が最大の出現率を示 すのはまどろみ乃至浅い睡眠時であることは一致した結 論である、我々の成績でも，図７に見る如く浅い睡眠時 に最もよく発生している。特に徐波の上に時折 spindles の重䁷する時期には K-eomplex が連綕的に出現してい る、これに対し，党醒時あるいは深睡眠時には K-com. plex の電位は非常に小さく，ほとえど認め難い

以上の観察上り我々性誘発反応の加算䉓位の大きさが 感覚刺激の强さ亚びに被検者の意識状態に影篗されるこ とを知つた，京た，意識状態が活よ゙一定に維持されてい， 硍りに抋いてのみ大きさけ感覚刺激の強さと大凡そ比
例関例にあることを明らかにした，被検者の意識が非常 に変動するときは感賞刺激による区応閾值は容易に移動

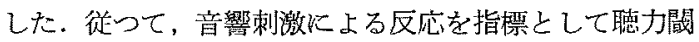

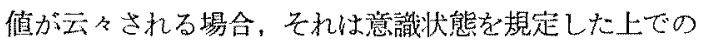
閣值であつて，被检者の状態を無視した閧值は意味がな いと思われる。

最後に䈍識状態による誘発反心の出琴率の相違老生理 学的に考察する. 图9にその機構を示小 本来 K-com-

図 9 意識状態々棌発反応登生機橉に関する考察

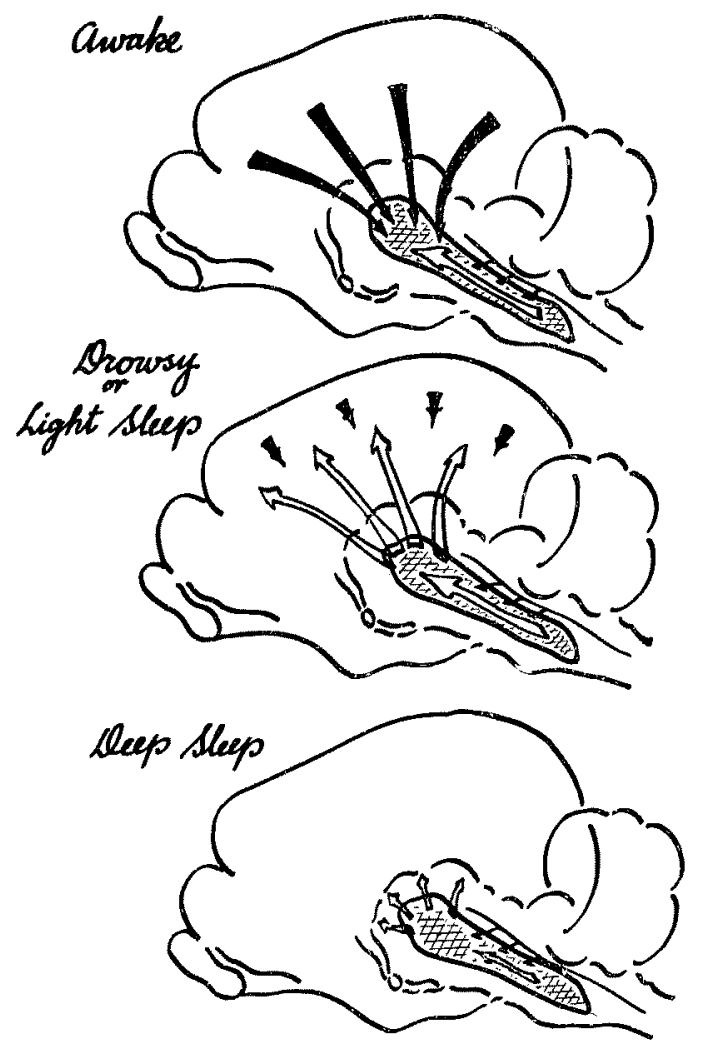

plex は感觉刺激インパルスが脳幹部で主路から分れて 所謂絧检体倵活系に入り，それが皮貿に投射されたもの とされている，先ず，覚醒時には皮質中枢から脳幹部に 刘しててこに流れ込も感覚入力を適当に調節する下行幽 機構が間断なく作動している。この系路纴すでに Mag. oun et $\left.\mathrm{al}^{42}\right)$ (1946), French et al ${ }^{43}$ ) (1955), Hernández-Peón 44) (1955), Dawson ${ }^{45)}$ (1958) により証明さ れている，元来，緸密で合理的機能を営む生体にはあら ゆる部位に多くの feedback systems が想定されてい

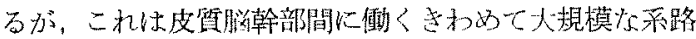


と考劣られる。これにより過剩な感覚入力は中枢に到邀 する以前に調節され，それが不足するとさは增幅され， 皮質には常に適度の入力が伝わるようになる. 党䝀時に はこの作用が強く働いて誘発電位を抑制しているが，皮 質活動がや小減退したまどろみ乃至浅睡眠状態ではその 抑制がとれて誘発電位が最大に皮質に投射される。ささ 飞睡眠が深くなると皮質活動とともに脳幹絧様体の機能 も低下し，誘発反応を若起する根源のものが休止してし まらと考えられる。

\section{第 5 章 結語}

脳波恥性反応を他営的聴検の指標として臨床的に応用 するに際し，誘発反応之音響刺激の強さ，被榆者の意識 状態との関係を電子加算機を用いて検索した。

一定の意識状態が保持されるときは誘発反応の大きさ ひいてはその出現性は音響刺激の強さと汪が直線的関係 を示した。しかし，意識状態が変動するとその関倸は複 雑となり，意識状態の因子が誘発反応の出現に上り大き く影響するように思われた。

被検者の意識状態が誘発電位の発生に決定的要素亡な ることから実際の臨床的聴検の他党的閾値の判定時，意 識状態が一定にしかも統一されねばならぬことが強調さ 机た。

誘発反応に対する感覚刺激の強さ及び意識状態との関 保が中枢神経系の生理学的機構上り考按された. 生体が 単純な機械系之異なる点はその活動に無数の feedback systems が㗢いていることである，未梢からの感覚性入 力はそのま〉で中枢に達することなく，多くの段階で中 枢からの帰還作用で調節される，この機能がこつでいう 意識状態に相当すると考兄られ，意識状態が微妙に变動 するとき音響刺激の強さ（入力）々锈発反応の大きさ （出力）との間には必ずしも一元的関係が存在しないこ とが推論された。

\section{文献}

1) Davis, H., Davis, P.A., Loomis, A.L., Harvey E.N. and Hobart, G.A.: Electrical Responses of the Human Brain to Auditory Stimulation during Sleep. J. Neurophysiot., 2: 500 514, 1939. Derbyshire, A.J. and Farley, J.C.: Sampling Auditory Responses at the Cortical Level Ann. OtoRhino-Laryng., 68: 675 697, 1959. 3) Suzuki, T. and Asawa, I.: Evoked Potentials of Waking Human Brain to Acoustic Stimuli. Acta Otolaryng., 48: 508 529, 1957.

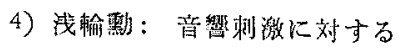

人間大脳誘発電位を钼察するための一新方法について, 日耳受, 62: 1143〜1153, 1959. 5) Barlow, J.S.: An Electronic Method for Detecting Evoked Res. ponses of the Brain and for Reproducing Their Average Form. EEG Clin. Neurophysiol., 9: 340 $343,1957.6$ 6) Goldstein, M.H.: Averaging Tech. niques Applied to Evoked Responses EEG Clin. Neurophysiol., Suppl. 20:59 63, 1961. 7) Doerfler, L.G.: Neurophysiological Clues to Auditory Acuity. J. Speech Hear. Dis., 13: 227 232, 1948. 8) Tato, J.M.: Electro-Encephalogic Auditive Threshold. Acta Otolaryng., Suppl 78: 151, 1949. 9) Marcus, R.E., Gibbs, E.L. and Gibbs, F.A.: Electroencephalography in Diagnosis of Hearing Loss in the Very Young Child. Dis. Nerv. Syst., 10: 170 173, 1949. 10) Marcus, R.E.: Hearing and Speech Problems in Children; Observations and Use of Electrocncephalography. A.M.A. Arch. Otolaryng., 53: 134 146, 1951. 11) Gicloll, S.H.: Qnantative. Determination of Hearing to Audiometric Frequencies in the Electroencephabogram. A.M.A. Arch. Otolaryng., 55: 597 601, 1952. 12) Perl, E.R., Galambos, R. and Glorig, A.: The Estimation of Hearing Threshold by Electroencephalography. EEG Clin. Neurophysiol., 5: 501 512, 1953. 13) Derbyshire, A.J., Wooley, P.V., Jr., McDermott, M. and Fraser, A.R.: The Use of the Electroencephalogram in the Evaluation of Hearing in Preschool Age Child. Amer. J. Dis. Child., 90: 649 650, 1955. 14) Derbyshire, A.J., Fraser, A. A., McDermott, M.and Bridge, A.: Audiometric Measurements by Electroencephalography. EEG Cl. in. Neurophysiol., 8: 467 478, 1956. 15) Derby. shire, A.J. and McDermott, M.: Further Contributions to the EEG Method of Evaluating Audito. ry Function. Laryngoscope, 68: 558 570, 1958.

16) Withrow, F.B. and Goldstein, R: An Electroencephalographic Procedure for Deternrinotion of Auditory Threshold in Children. Laryngoscope, 68: 1674 1699, 1958.

17) Ortiz-Estrada, P., Deut. sch, E. and Hernandez-Orozco, F.: An Electroencephalographic Method for Evaluation of Hearing in Children. Ann. Oto-Rhino-Laryng., 72 : 135 148, 


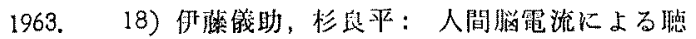
覚の客観的湖定，日耳奥，45:1544〜1545, 1939. 19) 山本繁，板侖秀：脳波による他覚的聴力検査について， 日耳多，57:727，1954。20）浅輸勲：音響刺激に よる覚醒時人間大脳の謡発電位とその他覚的㯖力検查法 への芯用，日耳鬾，62:743〜759，1959，21）板倉 秀：脳波之音響刺激，日耳出，60：712～762，19572。 22) 板倉秀: 他覚的㯖力検查法 (EEG Kょる法), Audiology, 2: 48〜49, 1959. 23) 河村正三, 藤田 史朗，鳥山稳，茂木しげ子，長烟正道，丸山博：脳波 による他覚的聴力检查, Audialogy, 2: 50 51, 1959. 24）河村正三，野口憲道，茂木しげ子，鳥山稳：脳波 聴力検查について，日耳歹，66:142,1963。25) 長 畑正道：譄波による聴力㭘查，小児科晾寮，24：414〜 419,1961 26) 坂本伸一郎, 本間利美, 今一郎:

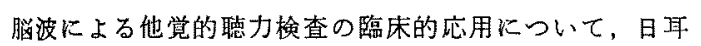
鼻, 66: 1076, 1963. $\quad$ 27) Davis, P.A.: Effects of Acoustic Stimuli on the Waking Human Brain. J. Neurophysiol., 2 : 494 499, 1949. 28) Abe, M.: Electrical Responses of the Human Brain to Acoustic Stimulus. Johoku J. Exper. Med., 60: 47 58, 1954. 29) Gastant, H.: Etude életctrographique chez l'homme et chez l'animal des décharges épileptiques dites «psychomotrics $\gg$ Rev. Neurol., 88: 310 352, 1953. 30) Bancaud, J., Block, V. et Paillard, J.: Contribution EEG à l'études des potentiels évoqués chez l'homme ru niveau du vertex. Rev. Neurol, 89 : 399 418, 1953, 31) Roth, M., Shaw, J. and Green, J.: The Form, Voltage Distrifution and Physiological Significance of the Kcomplex. EEG Clin. Neurophysiol., 8: 385 402, 1956. 32) 北尻金三郎：音響刺激の脳波に及法す影

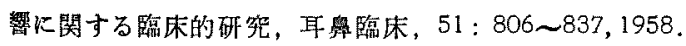
33) Gastaut, Y.: Negative Spikes Evokee at the Vertex. Their Psychophysiologic and Pathologic Significance. EEG Clin. Neurophysiol., 6: 161, 1954. 34) 鳥山稳, 松崎力: 感覚刺激による皮質誘発電位 $\mathrm{K}$ complex の臨床的応用とその本態について，耳鼻展望， 予定. 35) Derbyshire, A.J., Rempel, B., Forbes, A. and Lambert, E.F.: The Effects of Anes- thetics on Action Potentials in the Cerebral Cortex of the Cat. Amer, J. Physiol., 116: 577 596, 1936. 36) Forbes, A. and Morison, B.R.: Cortical Response to Sensory Stimulation under Deep Barbiturate Narcosis. J. Neurophysiol., 2: 112 128, 1939. 37) Galambos, R.: Microelectrode Studies on $\mathrm{Me}$ dial Geniculate Body of Cat. III Response to Pure Jones J. Neurophysiol., 15: 381 400, $1952 . \quad 38$ ) Hind, J.E., Goldberg, J.M., "Greenwood, D.D. and Rose, J.E.: Some Discharge Characteristics of Sin. gle Neurons in the Inferior Colliculus of the Cat. II Jiming of the Discharges and Observations on Binaural Stimulation. J. Neurophysiol, 26:321 341, 1963.39）切替一郎，竹尾康男，佐藤恒正，設湶表也， 寺尾樹, 松崎力: 㯖性反応時間に関する检查知見, Audiology, 7: 71 72, 1964 . 40) Loomis, A.L., Harvey, E.N. and Hobart, G.A.. Cerebral States during Sleep As Studied by Human Brain Potentials. J. exp. Psychol., 21 : 127 144, 1937. 41) Davis, H., Davis, P.A., Loomis, A.L. and Harvey, E.N.: Changes in Human Brain Potentials during the Onset of Sleep. Science, 86: 448 450, 1937. 42) Magoun, H.W. and Rhines, R.: An Inhibitory Mechanism in the Bulbar Reticular Formation. J. Neurophysiol., 9: 165 171, 1946. 43) French, $J$. D., Hernández-Peón, $R$. and Livingston, R.B.: Prolections from Cortex to Cephalic Brain Stem (Reticular Formation) in Monkey. J. Neurophysiol., 18: 74 95, 1955. 44) Hernández-Pé́n, $R$ and Hagbarth, K.-E.: Interaction between afferent and Cortically Induced Reticular Response. J. Neurophysiol., 18: 44 55, $1955 . \quad$ 45) Dawson, G.D.; Central Control of Sensory Inflow. EEG Clin. Neurophysiol., 10: 351, 1958.

稳を終るに当り䅂始御愁切なる御指導御校閲を睤 つた恩師切炇一即教嗳に衰心より謝意を衰わします。

（原媳到着 $=$ 炤和 39.9 .26 日） 